\author{
Marcin Wałdoch \\ (Kazimierz Wielki University, Bydgoszcz, Poland) \\ https://orcid.org/0000-0002-8778-1780 \\ E-mail: waldoch@ukw.edu.pl
}

\title{
Polska Partia Robotnicza w powiecie chojnickim: geneza, idee, struktura, ludzie i działalność polityczna (1945-1948)
}

\author{
Polish Workers' Party in Chojnice County: Genesis, Ideas, Structure, People \\ and Political Activity (1945-1948)
}

\begin{abstract}
The issues regarding PPR, its structure, people and political activity are well explored on the central level, and in some cases on the regional level as well. There have been no studies so far about PPR in Chojnice County in years 1945-1948, however. Thus, an author decided to fill this gap in by making a study on the basis of primary sources. The foundation for this task are two hypotheses. The first one is that political elites of PRR in Chojnice were part of the "enforced authorities" in the process of Poland sovietization. The second hypothesis, an auxiliary one, is that political phenomena resulting from PPR political activity in Chojnice County were analogical to those in then Poland as a whole in accordance to Marxism - Leninism ideology.
\end{abstract}

Key words: Polish Workers' Party, Chojnice, sovietization, communism, political parties, political elites, local politics

\begin{tabular}{|c|c|c|c|c|}
\hline \multicolumn{5}{|c|}{ PUBLICATION INFO } \\
\hline (IH) & UMCS & "Th: UMCS & $\begin{array}{l}\text { e-ISSN: } 2449-8467 \\
\text { ISSN: } 2082-6060\end{array}$ & OPEN@ACCESS \\
\hline \multicolumn{5}{|c|}{$\begin{array}{l}\text { THE AUTHOR'S ADDRESS: Marcin Wałdoch, the Faculty of Political Science and Administration of the Kazimierz } \\
\text { Wielki University, } 12 \text { J. Poniatowski Street, Bydgoszcz 85-671, Poland }\end{array}$} \\
\hline \multicolumn{5}{|c|}{$\begin{array}{l}\text { SOURCE OF FUNDING: Statutory Research of the Faculty of Political Science and Administration of the } \\
\text { Kazimierz Wielki University }\end{array}$} \\
\hline $\begin{array}{l}\text { SUBMITTED } \\
2020.02 .06\end{array}$ & & $\begin{array}{l}\text { ACCEPTED: } \\
2020.12 .01\end{array}$ & $\begin{array}{l}\text { PUBLISHED ONLINE: } \\
2021.06 .30\end{array}$ & (c) \\
\hline \multicolumn{3}{|c|}{$\begin{array}{l}\text { WEBSITE OF THE JOURNAL: } \\
\text { https://journals.umcs.pl/rh }\end{array}$} & $\begin{array}{l}\text { EDITORIAL } \\
\text { COMMITTEE E-mail: } \\
\text { reshistorica@umcs.pl }\end{array}$ & Crossref doi \\
\hline
\end{tabular}




\section{STRESZCZENIE}

Tematyka związana z PPR, jej struktura, ludzie i działalność polityczna jest dokładnie poznana, w odniesieniu do centralnych struktur partii, a w niektórych przypadkach również do struktur regionalnych. Jak dotąd jednak nie ma żadnych opublikowanych studiów nad PPR w powiecie chojnickim w latach 1945-1948. Stąd autor zdecydował się wypełnić tę lukę poznawczą poprzez studia nad materiałami źródłowymi. W stadium tym przyjęto dwie hipotezy. Pierwsza, stanowiącą przypuszczenie, że elity PPR w Chojnicach były elementem "narzuconej władzy” w procesie sowietyzacji Polski. Druga hipoteza, pomocnicza, stanowi przypuszczenie, że zjawiska polityczne, wynikające z działalności politycznej PPR na ziemi chojnickiej, były analogiczne do zjawisk zachodzących w całej Polsce, na szczeblu lokalnym, w wyniku budowania struktur i utożsamiania władzy państwowej z PPR zgodnie z ideologią marksizmu-leninizmu

Słowa kluczowe: Polska Partia Robotnicza, Chojnice, sowietyzacja, komunizm, partie polityczne, elity polityczne, polityka lokalna

\section{WSTĘP}

Chojnice przed wybuchem II wojny światowej leżały na zachodnio-północnych rubieżach państwa polskiego i były jednym z pierwszych punktów oporu wobec agresji niemieckiej - już od godz. 4:23 1 września 1939 r., kiedy z niemieckiego pociągu pancernego na chojnickiej stacji cywilów i żołnierzy Wojska Polskiego zaatakowali żołnierze Wehrmachtu ${ }^{1}$. Okres okupacji niemieckiej w latach 1939-1945 Chojnice przeszły bardzo ciężko, tracąc ludność, a szczególnie swą klasę średnią i wyższą². Po osiągnięciu Chojnic przez wojska sowieckie w drugiej dekadzie lutego $1945 \mathrm{r}$. $\mathrm{w}$ wyniku operacji koszalińskiej i po intensywnych walkach o miasto ${ }^{3}$ struktury nowej władzy podległej Rządowi Tymczasowemu RP zaczęła tworzyć „pierwsza trójka”, czyli członkowie Polskiej Partii Robotniczej (PRR), którzy do Chojnic przybyli po opanowaniu miasta przez Sowietów. Wśród "pierwszej trójki” byli: Jan Janek por. Urzędu Bezpieczeństwa Publicznego, starosta Tadeusz Rześniowiecki oraz przewodniczący PPR na powiat chojnicki por. Marian Śmigielski. Ich atrybutem było

\footnotetext{
1 A. Lorbiecki, M. Wałdoch, Chojnice 1939, Warszawa 2014, s. 87-102.

2 Ludność powiatu chojnickiego w latach 1945-1948 wahała się przez wzgląd na ruchy migracyjne w zakresie 65-72 tys. mieszkańców. Miasto Chojnice liczyło zaś nieco ponad 13 tys. mieszkańców, kiedy przed wybuchem II wojny światowej było miastem 17-tysięcznym. Zob. B. Głębowicz, W Polsce Ludowej, w: Chojnice. Dzieje miasta i powiatu, red. S. Gierszewski, Wrocław-Warszawa-Kraków-Gdańsk 1971, s. 262-263.

3 Walka o Chojnice trwała kilka dni, niemiecka załoga opuściła miasto dopiero po okrążeniu miasta przez 70. Armię sowiecką. Zob. E. Murawski, Bój o Pomorze. Ostatnie walki obronne na wschodzie, tłum. G. Bębnik, Oświęcim 2015, s. 97-100.
} 
posiadanie dokumentów potwierdzających ich status jako przedstawicieli nowej władzy politycznej i państwowej na terenach zajmowanych przez Armię Robotniczo-Chłopską. Próbując rozpoznać teren, między innymi ziemi chojnickiej w czasie wojny, 22 września 1944 r. Sowieci zrzucili w Bory Tucholskie desant „Wołga”, w skład którego wchodziło siedmiu Polaków i dwóch oficerów sowieckich. Grupą kierował por. Jan Miętki, a celem jej działania był wywiad ${ }^{4}$.

Przed 1945 r. w Chojnicach komuniści nie prowadzili zorganizowanej działalności ani nie posiadali swoich struktur, co mogło zapowiadać liczne bariery natury społeczno-politycznej dla nowej władzy. Jednak na terenie województwa pomorskiego działały przed 1939 r. struktury Komunistycznej Partii Robotniczej Polski (KPRP) oraz od 1925 r. Komunistycznej Partii Polski. W tamtym okresie do głównych ośrodków działalności komunistycznej na Pomorzu należały Grudziądz, Gdynia i Toruń, ale nie Chojnice ${ }^{5}$. Choć w Chojnicach KPRP podejmowało próbę (bez powodzenia) rozwoju działalności w środowisku kolejarskim ${ }^{6}$. Wnioskuje się więc, że brak poparcia społecznego na terenie powiatu chojnickiego w okresie międzywojennym dla idei komunizmu mógł zapowiadać trudności dla wdrożenia tej ideologii $\mathrm{w}$ okresie powojennym.

Jedyne wystąpienia robotnicze, do których dochodziło $\mathrm{w}$ stolicy powiatu chojnickiego $\mathrm{w}$ okresie międzywojennym, prowadzone były siłami niekomunistycznej Polskiej Partii Socjalistycznej (PPS). Natomiast wcześniejsze strajki, jeszcze $\mathrm{w}$ okresie zaboru pruskiego, datowane są od pierwszego strajku robotników budowalnych w Chojnicach w $1905 \mathrm{r}$. oraz rok późniejszego strajku murarzy. W Chojnicach działali pojedynczy komuniści, znani na Pomorzu Gdańskim w okresie międzywojennym, tacy jak: Piotr Kurtz oraz Jan Włodarczyk, którzy byli mężami zaufania w 1922 r. na okręg wyborczy Grudziądz z ramienia komunistycznego Związku Proletariuszy Miast i Wsi w trakcie wyborów do Sejmu. KPRP posiadała swoich pojedynczych stronników w Chojnicach, ale w tej mierze znany jest jedynie M. Gobłębiewski (brak imienia w dokumentach). W 1929 r. doszło do strajku robotników rolnych w wioskach ziemi chojnickiej. Z kolei wspomniana PPS organizowała w Chojnicach marsze robotników 1 maja z okazji Światowego Dnia Pracy. 21 stycznia 1932 r. doszło do masowego strajku robotników i słabo sytuowanych chojniczan.

4 M. Wałdoch, Polityka faktów dokonanych: Chojnice od 15 lutego do 9 maja 1945 roku we władzy Armii Czerwonej i Polskiej Partii Robotniczej, "Zeszyty Chojnickie” 2016, 32, s. 53.

5 Ibidem.

6 R. Wapiński, Życie polityczne Pomorza w latach 1920-1939, Warszawa-Poznań-Toruń 1983, s. 81. 
W 1980 r. komuniści z terenu dawnego powiatu chojnickiego szacowali, że mieli w swych szeregach około 80 „weteranów zmagań o prawa pracownicze i emancypację robotników" ${ }^{\prime \prime}$, ci jednak w większości byli już działaczami powojennymi. Komuniści uzyskiwali też nikłe poparcie w trakcie wyborów parlamentarnych. Podczas wyborów w 1922 r. do Sejmu Ustawodawczego około $41 \%$ głosów zdobyło na Pomorzu Narodowe Stronnictwo Robotników, była to jednak partia odwołująca się nie tylko do ludzi pracy, ale przede wszystkim do ducha narodowego i opowiadająca się za unifikacją Pomorza z Polską a działacze partii odcinali się od idei socjalistycznych oraz tzw. walki robotniczej. Późniejsze, komunizujące organizacje i partie polityczne do 1939 r. nie znalazły poparcia wśród mieszkańców Pomorza. Jak pisał o tym fakcie Roman Wapiński: „[...] szansę zdobycia masowych, a zarazem trwałych wpływów wśród robotników polskich Pomorza miały jedynie te organizacje, które potrafiły łączyć walkę o poprawę położenia robotników z dostrzeganiem polskiego interesu narodowego. To decydowało o rzeczywistej marginalności wpływów ruchu komunistycznego, także i w latach trzydziestych" ${ }^{8}$. Właśnie w latach trzydziestych główną reprezentantką interesów robotniczych stała się głównie na Pomorzu PPS, choć poparcie dla niej znacznie ustępowało poparciu, jakiego Pomorzanie udzielali ruchowi narodowemu ${ }^{9}$. Teren powiatu chojnickiego był przedmiotem zainteresowania wywiadu sowieckiego w okresie międzywojennym ${ }^{10}$, co mogło mieć przełożenie na poziom wiedzy o życiu politycznym oraz elitach lokalnych i regionalnych tej części Polski.

Chojnice ucierpiały materialnie $\mathrm{w}$ trakcie wojny nie tylko $\mathrm{w}$ wyniku działań wojennych, ale także powojennej grabieży i niszczenia mienia przez żołnierzy Armii Czerwonej, która stacjonowała na terenie Pomorza Gdańskiego do 1947 r. ${ }^{11}$ Dodatkowo, negatywnie na obraz „nowej władzy" wpływały deportacje ludności polskiej do ZSRS. Do czerwca 1945 r. z powiatu chojnickiego deportowano 1172 osoby. Tylko w jednym

7 M. Wałdoch, Obraz podziałów socjopolitycznych wsi chojnickiej w karnawale "Solidarności", „Zeszyty Chojnickie” 2015, 31, s. 110-112. Poparcie dla komunistów występujących jako Związek Proletariuszy Miast i Wsi w wyborach do Sejmu w 1922 r. wynosiło w powiecie chojnickim poniżej 1\%. PPS w 1928 r. w wyborach do Sejmu zdobył 8\% głosów. Natomiast Centrolew uzyskał w 1930 r. 31\%. Zob. R. Wapiński, Życie, s. 90-93, 144-145, 174.

8 R. Wapiński, Ruch robotniczy na Pomorzu w latach 1920-1939, w: 100 lat ruchu robotniczego na Pomorzu, red. M. Wojciechowski, Toruń 1983, s. 68.

9 Ibidem, s. 51-74.

10 M. Wałdoch, Sprawa o szpiegostwo Józefa Maculewicza, podkomisarza Straży Celnej w Chojnicach $w$ dokumentach instytucji bezpieczeństwa II RP (1924-1925). Próba rekonstrukcji afery szpiegowskiej, „Studia Gdańskie. Wizje i rzeczywistość” 2014, 11, s. 149-164.

11 G. Baziur, Armia Czerwona na Pomorzu Gdańskim 1945-1947, Warszawa 2003. 
z obozów pracy nr 506 w Kopiejsku koło Czelabińska życie straciły $44 \mathrm{z} \mathrm{nich}^{12}$. Odczuwano w okresie powojennym efekty wywozu całych fabryk z Chojnic, tylko w okresie luty-kwiecień Sowieci wywieźli z miasta 11 fabryk. Chojnice należały do miast najbardziej dotkniętych zniszczeniami i pożogą wojenną na Pomorzu Nadwiślańskim ${ }^{13}$. Ponadto liczne były gwałty na kobietach, narastały negatywne zjawiska, jak szabrownictwo, tuż po przejściu frontu straty materiałowe nowe władze szacowały na $80 \%$. Brakowało zaopatrzenia w sklepach i ewentualnych zakładach pracy $^{14}$. Do tego komuniści po przybyciu na teren powiatu chojnickiego angażowali się $\mathrm{w}$ „,ściąganie rzeczowych świadczeń wojennych” od ludności miejscowej ${ }^{15}$.

Kolejnym negatywnym zjawiskiem była parcelacja majątków ziemskich wynikająca z przyjętego przez PKWN i Rząd Tymczasowy programu tzw. reformy rolnej. Na terenie powiatu chojnickiego w pierwszej kolejności wyodrębniono sto majątków o areale powyżej 100 ha, które wskazano do parcelacji. Likwidacja majątków ziemskich i idąca za tym likwidacja pozostałej przy życiu namiastki ziemiaństwa powiatu chojnickiego przebiegła bardzo sprawnie i zajęła komunistom zaledwie niecałe dwa miesiące, od połowy marca do 8 maja 1945 r., kiedy rozwiązano brygady parcelacyjne. $\mathrm{W}$ tym okresie rozparcelowano prawie 24 tys. ha ${ }^{16}$. Nastroje społeczne nie były zatem dla komunistów korzystne, jeśli więc z czasem znajdowali członków i aktywistów w społeczeństwie pomorskim, to nie ze względu na ideologiczną zgodność, ale przez wzgląd na chęć zapewnienia sobie ochrony i poparcia dla posiadanych aspiracji ekonomicznych. Na Pomorzu do PPR wstępowali także chłopi, ale głównie dla zapewnienia sobie stanu posiadania $\mathrm{w}$ objętych majątkach poniemieckich. Ponadto na Pomorzu potężne wpływy miał Kościół katolicki, z którego wiernymi i kapłanami PPR szybko wszedł w otwartą konfrontację na ziemi chojnickiej w 1947 r., np. z księdzem Józefem Wrycza, który cieszył się nie tylko popularnością, ale i autorytetem. Choć uznaje się, że komuniści chcieli w początkowym okresie zdobywania gruntu pod

12 M. Golon, Polityka radzieckich władz wojskowych i policyjnych na Pomorzu Nadwiślańskim w latach 1945-1947, Toruń 2001, s. 81.

13 Ibidem.

14 Archiwum Państwowe w Bydgoszczy [dalej: APB], Starostwo Powiatowe Chojnickie w Chojnicach, sygn. 21, k. 4.

15 R. Kozłowski, Polska Partia Robotnicza w województwie pomorskim 1942-1948, Bydgoszcz 1985, s. 75.

16 Archiwum Delegatury Instytut Pamięci Narodowej w Bydgoszczy [dalej: ADIPN By], Wojewódzki Urząd Spraw Wewnętrznych w Bydgoszczy [1945] 1983-1990 [dalej: WUSWB], Wojewódzki Urząd Bezpieczeństwa Publicznego w Bydgoszczy 1945-1954 [dalej: WUBPB], sygn. IPN By 049/1, s. 13, 15, 18. 
nogami kamuflować niechęć elit PPR do Kościoła ${ }^{17}$. UB zainteresowało się rzekomą antypaństwową działalnością ks. J. Wryczy po doniesieniach Sekretariatu PPR w Karsinie w marcu 1947 r. Wskazywano, że ks. J. Wrycza był przed wojną „zaciętym Endekiem” i występował w sposób radykalny przeciwko PPR. Według relacji członków PPR z Karsina ks. J. Wrycza miał publicznie ich wyzywać od „[...] komunistów, socjalistów, służalczyków komunizmu [...]"18 oraz powtarzał wielokrotnie, że „Bolszewickie Rządy się niedługo skończą $[\ldots]^{\prime 19}$.

Niewątpliwie działania PPR w Polsce, a w tym i w Polsce lokalnej, były elementem szerszego procesu sowietyzacji Europy ${ }^{20}$. Był to jednak proces, który Józef Stalin starał się maskować, bowiem przyjął początkowo, że należy stosować "narodową drogę do socjalizmu”. Stalin w początkowym okresie zmagań o przejęcie Polski pod swoje wpływy, czyli w 1943 r., wychodził z założenia, że sowietyzowanie krajów sąsiednich do ZSRS może uniemożliwić dalszą ekspansję komunizmu. Dlatego, jak pisała Krystyna Kersten: „,...] Stalin tak często i dobitnie powtarzał, iż nie jest jego celem komunizowanie Polski" ${ }^{21}$. Żeby włączyć PPR do działań państwa podziemnego, Sowieci podjęli próbę rozmów z Delegaturą Rządu w lutym 1943 r., celem „równouprawnienia” PPR względem innych partii politycznych, licząc na wejście, jeszcze podczas emigracji, komunistów polskich w skład koalicyjnego rządu. Warunki, jakie Delegatura Rządu stawiała przedstawicielom PPR, były dla komunistów nie do przyjęcia: mieli oni publicznie odciąć się od Kominternu, a także uznać Rząd RP na uchodźstwie w Londynie, uznać integralność terytorialną RP i poddać się pod zwierzchnictwo prezydenta i Rządu RP. Przyjmowaniu jednak PPR do współpracy politycznej pośrednio przeciwstawiał się także gen. Władysław Sikorski, który nawoływał w korespondencji do Polski do odcinania się od środowisk głoszących potrzebę sowietyzacji Polski. Wszelkie rozmowy pomiędzy Delegaturą Rządu RP a PPR straciły sens po wypowiedzeniu stosunków dyplomatycznych przez ZSRS 25 kwietnia $1943 \mathrm{r}^{22}$

Jak powstała PPR? Na ten temat powstała liczna literatura. Dla porządku wywodu należy jednak wskazać, że PPR została stworzona

17 R. Kozłowski, Przyczynek do dziejów ruchu robotniczego w woj. pomorskim w latach 19451948, w: 100 lat, s. 124, 139-141.

18 APB, Komitet Powiatowy Polskiej Partii Robotniczej w Chojnicach [dalej: KPPPRCh], sygn. 7, nlb., Sekretariat PPR w Karsinie do Powiatowego Sekretariatu PPR w Chojnicach, Karsin, 24 III 1947.

19 Ibidem.

20 N. Pietrov, Nowy ład Stalina. Sowietyzacja Europy 1945-1953, Warszawa 2011, passim.

21 K. Kersten, Narodziny systemu władzy. Polska 1943-1948, Warszawa 1984, s. 20-21.

22 Ibidem, s. 22-23. 
z inicjatywy J. Stalina, który 27 sierpnia 1941 r. określił jej program polityczny, ukrywając w jej nazwie komunistyczną naturę nowej formacji politycznej. Postąpił tak głównie w obawie przed postawami Polaków, gremialnie niechętnym idei komunizmu. PPR w swojej pierwszej odezwie z 16 września 1941 r. ujawniła program i projekcje terytorialne. Przede wszystkim winnych upadku państwa polskiego wskazywano w marszałku Edwardzie Śmigłym-Rydzu oraz w ministrze spraw zagranicznych Józefie Becku. Zapowiadano walkę z kapitalizmem i III Rzeszą Niemiecką. Wrogami byli też Rząd RP na uchodźstwie oraz wszyscy, którzy odczuwali sentyment wobec rządu w Polsce sprzed wybuchu II wojny światowej. Wzywano także do walki partyzanckiej i walki z wrogami PPR poprzez promowanie hasła o konieczności otwarcia „drugiego frontu'. PPR pozostawała całkowicie zależna od woli politycznej Moskwy ${ }^{23}$. Organizacyjnie PPR wzorowana była na Wszechzwiązkowej Partii Komunistycznej. Charakterystyczne dla tego modelu było budowanie elity partyjnej według systemu tzw. trójek - sekretarza partii, jej skarbnika i technika. W Polsce, gdzie było to możliwe, PPR rozwijała się dzięki kontaktom przedwojennym z lokalnymi działaczami komunistycznymi, tam gdzie było to niemożliwe, komórki partii tworzyli między innymi sowieccy spadochroniarze. Niemniej rozwijanie PPR w partię masową stanowiło dla komunistów spore wyzwanie. W partii obowiązywał tzw. centralizm demokratyczny. Podstawową jednostką była komórka partyjna, która podlegała komitetom miejskim lub dzielnicowym oraz powiatowym. Istniała zależność komitetów miejskich wobec komitetów powiatowych. W komitetach miejskich zasiadało od 7 do 11 członków, zaś w komitetach powiatowych od 9 do 17 członków. Nad komitetem powiatowym władzę miały komitety obwodowe obejmujące teren województwa, które podlegały bezpośrednio Komitetowi Centralnemu PPR. Skład partyjnych komitetów miejskich wybierano na walnych zebraniach miejskich. Z członków komitetów wybierano jego egzekutywę, a na czele komitetów stał sekretarz PPR. Istotną rolę posiadał Wydział Kadr odpowiednich komitetów PPR, którego zadaniem było umieszczanie członków partii w administracji państwowej, samorządowej, bezpieczeństwa publicznego oraz samym aparacie partyjnym i zakładach pracy. $\mathrm{W}$ instrukcji PPR wskazywano, że jest ona odpowiedzialna za walkę z "reakcją polską". Zadaniem PPR było wniknąć w każdą instytucję życia społecznego, każdą fabrykę i każdy zakład ${ }^{24}$. Na gruncie myśli politycznej

23 P. Gontarczyk, Polska Partia Robotnicza. Droga do władzy (1941-1944), Warszawa 2006, s. $65-80$.

24 D. Magier, Instrukcja organizacyjna Polskiej Partii Robotniczej z 10 września 1944 roku, „Res Historica” 2018, 45, s. 343-356. 
jednym z azymutów działań PPR była kategoria wroga, którą rozumiano dwojako - jako wroga obiektywnego (istniejącego na bazie wskazania, arbitralnego rozstrzygnięcia) oraz wroga subiektywnego, określanego na podstawie działań przeciwko partii. Wrogami stawali się dla PPR „obcy klasowo", ziemianie, burżuazja, przedstawiciele wolnych zawodów, przedsiębiorcy i rzemieślnicy, kupcy i chłopi, a uogólniając, po prostu wszyscy, którzy nie mogli być sklasyfikowani jako proletariat. Dla PPR wrogami stawali się też: Rząd RP na uchodźstwie, wszyscy, którzy nie chcieli przyłączyć się i współpracować z komunistami, ogólnie więc - reakcja, której pojemność znaczeniową rozszerzano poprzez stosowanie całego repertuaru inwektyw, z których najpopularniejszą była "faszyści”, ,zdrajcy i kolaboranci”. Oskarżenia o faszyzm, zdradę i kolaborację stawały się sposobem na niewygodne komunistom środowiska, grupy społeczne i jednostki. Po utworzeniu 28 czerwca 1945 r. Tymczasowego Rządu Jedności Narodowej z udziałem Polskiego Stronnictwa Ludowego (PSL), to ostatnie stało się kolejnym wrogiem na liście komunistów. Do obozu wrogów „demokracji” zaliczano także żołnierzy polskiego podziemia zbrojnego. Opozycja wobec PPR została unieszkodliwiona do jesieni 1947 r., a przypieczętowana sukcesem wyborczym PPR. Po rozbiciu zorganizowanej opozycji politycznej PPR aż do konferencji zjednoczeniowej w grudniu 1948 r. przyjęła kurs walki ze wszystkimi grupami społecznymi, które stanowiły realne lub wyimaginowane zagrożenie. PPR w związku z wyznaczonymi w Moskwie celami potrzebowała wroga, który zmieniał się wraz ze zmianą stawianych przed partią zadań25. W projektowanym nowym systemie politycznym dla Polski odrzucono ideę pluralizmu politycznego i założono, że rola dominująca na scenie politycznej przypadnie PPR. Partia komunistyczna stała się w ten sposób czynnikiem decydującym o wszelkich procesach politycznych i ekonomicznych, a przy tym była naczelną instytucją panującą i spinającą aparat bezpieczeństwa państwa ${ }^{26}$.

Celem niniejszej publikacji jest próba charakterystyki zjawisk i zdarzeń politycznych związanych $\mathrm{z}$ funkcjonowaniem PPR na terenie powiatu chojnickiego w latach 1945-1948.

25 K. Trembicka, Od wroga klasowego do wroga etnicznego - ewolucja komunistycznej myśli politycznej na przykładzie Polskiej Partii Robotniczej i Polskiej Zjednoczonej Partii Robotniczej w latach 1942-1968, „Humanities and Social Sciences” 2015, 20, s. 175-178.

26 J. Wrona, System polityczny w Polsce w latach 1944-1948, „Pamięć i Sprawiedliwość" 2005, 2 (8), s. 54. 


\section{ZAŁOŻENIA TEORETYCZNE. HIPOTEZA, PYTANIA BADAWCZE I MATERIAŁY ŹRÓDŁOWE}

Teoretyczną podstawą prowadzonego badania jest teoria elit politycznych, zgodnie z ujęciem, że władza jest sprawowana przez ludzi pełniących kluczowe stanowiska w instytucjach życia publicznego. Według komunistów, przez wzgląd na słabość tkanki społecznej oraz poniesione straty w czasie wojny, w okresie tuż powojennym dopuszczano możliwość współpracy z wybranymi przedstawicielami elit przedwojennych. Celem komunistycznej elity politycznej była sowietyzacja i podporządkowanie Polski stalinowskiemu planowi sowietyzacji całej Europy Środkowo-Wschodniej. W tym zadaniu J. Stalin rolę pierwszoplanową przypisał PPR, którą „obudowano" koncesjonowanymi organizacjami społecznymi. Członkowie PPR, jak pisze Janusz Sztumski, w drodze rozwoju partii posługiwali się bodźcami pozytywnymi (obietnica szybkiej kariery), jak i negatywnymi (rekrutacja poprzez terror i zastraszanie). „Ludowy rodowód" części elit PPR, a później Polskiej Zjednoczonej Partii Robotniczej (PZPR), wynikał z dwóch faktów: szybkiej parcelacji ziemi po wejściu wojsk sowieckich oraz możliwości szybkiego awansu społecznego, co nie było możliwe dla chłopstwa międzywojennego. PPR od momentu zakiełkowania na danym terenie, aż do czasu kongresu zjednoczeniowego w 1948 r. pozostawała jedynym ośrodkiem władzy. Elity skupione wokół PPR stawały się tylko legitymacją dla utrzymywania i pogłębiania zależności Polski od ZSRS. Wśród elit komunistycznych, członków PPR, byli obok oportunistów, konformistów i karierowiczów także komuniści z „krwi i kości”, propagujący idee internacjonalizmu mas pracujących i sowieckiej propagandy ${ }^{27}$. Drugim odniesieniem teoretycznym jest teoria centrum-peryferie Steina Rokkana, według której ośrodkiem dominującym staje się centrum władzy, natomiast peryferia stawiają opór działaniom centrum władzy, w których centrum dąży do integracji i unifikacji. $\mathrm{W}$ toku istniejącego napięcia centra narzucają swoje wartości polityczne, normy, ideologię, język i kulturę peryferiom oraz elitom politycznym peryferii. Peryferia zaś dążą do wypracowania sobie ścieżek kompensacji podległości wobec centrum ${ }^{28}$.

Dla całości prowadzonego badania przyjęto metody decyzyjną i leksykalną. Wykonano analizę przyczynową materiałów źródłowych oraz ich syntezy narracyjno-nomonologicznej w odniesieniu do przyjętej

\footnotetext{
27 J. Sztumski, Elity ich miejsce i rola w społeczeństwie, Katowice 2007, s. 126-136.

28 Zob. T. Zarycki, Interdyscyplinarny model stosunków centro-peryferyjnych. Propozycje teoretyczne, „Studia Regionalne i Lokalne” 2007, 1 (27), s. 5-26.
} 
podstawy teoretycznej, hipotezy oraz pytań badawczych ${ }^{29}$. W cytowanych dokumentach zachowano pisownię oryginalną zaopatrzoną w cudzysłów.

Hipotezą prowadzonego badania jest przypuszczenie, że elity polityczne PPR w Chojnicach stanowiły element "narzuconej władzy" w procesie sowietyzacji Polski po 1944 r. Hipotezę pomocniczą stanowi przypuszczenie, że zjawiska polityczne, wynikające z działalności politycznej PPR na ziemi chojnickiej, były analogiczne do zjawisk zachodzących w całej Polsce, na szczeblu lokalnym, w wyniku budowania struktur i utożsamiania władzy państwowej z PPR zgodnie z ideologią marksizmu-leninizmu. Dla tak postawionych hipotez postawiono następujące pytania badawcze:

1. Jak lokalne elity PPR w powiecie chojnickim realizowały zadanie komunizacji/sowietyzacji?

2. Jak „chojniccy” komuniści postrzegali reżim polityczny panujący W II RP?

3. W kim komuniści lokalni dostrzegali swoich wrogów, a w kim sojuszników?

4. W jakim stopniu lokalne struktury PPR podlegały zmianom politycznym i ideowym, jakie wykazywały swoistości?

5. Jaką wizję organizacji życia politycznego posiadali i wyrażali członkowie PPR w Chojnicach i powiecie chojnickim?

Trzon analizowanych materiałów źródłowych stanowiły dokumenty znajdujące się w Archiwum Państwowym w Bydgoszczy (akta Starostwa Powiatowego w Chojnicach z lat 1945-1950, akta PPR i PPS) oraz w Archiwum Delegatury Instytut Pamięci Narodowej w Bydgoszczy (dokumenty powstałe w wyniku działalności Powiatowego Urzędu Bezpieczeństwa w Chojnicach).

\section{STAN BADAŃ}

Dotąd pośród licznych badań nad dziejami i działalnością PPR nie powstała żadna opublikowana praca dotycząca tej partii politycznej na ziemi chojnickiej ${ }^{30}$. W historiografii lokalnej i regionalnej zagadnienie roli PPR w kształtowaniu warunków życia politycznego jest marginalizowane. Przykładem tego są takie publikacje jak Dzieje Chojnic, gdzie znajduje się podrozdział Polityczny kształt władzy, w którym na około 14 stronach opisano ogólne relacje pomiędzy organizacjami politycznymi i partiami politycznymi w mieście i powiecie w okresie 1945-1948, zaznaczając

\footnotetext{
29 A. Chodubski, Wstęp do badań politologicznych, Gdańsk 2006, s. 130-131, 185-186.

30 Zob. R. Kozłowski, Polska; idem, Przyczynek.
} 
dążenie PPR do dominacji politycznej ${ }^{31}$. Paradoksem dziejów jest fakt autorstwa historii politycznej Chojnic tego okresu, bowiem pisał go były funkcjonariusz ORMO, członek PZPR oraz wieloletni redaktor naczelny organu prasowego PZPR, czyli "Gazety Pomorskiej” 32 . Zaś w historiografii okresu PRL aktywność PPR na ziemi chojnickiej przedstawiono zdawkowo, tworząc u odbiorcy obraz legalności działalności PPR i oddając jej rzekomo demokratyczny charakter ${ }^{33}$.

W toku pracy badawczej ustalono, że do przeważającej większości dokumentów PPR badacze sięgali w latach osiemdziesiątych XX w., ale nikt $\mathrm{z}$ nich nie wykonał nigdy $\mathrm{w}$ zachowanych źródłach kompleksowej kwerendy na temat tej partii w powiecie chojnickim. Natomiast archiwiści ustalili, że w materiałach chojnickiego powiatowego PPR brakuje przede wszystkim protokołów posiedzeń plenarnych z lat 1945-1946. Brakuje też akt Komisji Rewizyjnej. Przyjmuje się, że zachowało się około 50-70\% akt $\mathrm{PPR}^{34}$. W połowie lat osiemdziesiątych $\mathrm{XX} \mathrm{w}$. zatrzymały się badania nad pomorskim PPR, a nad chojnickim nie były prowadzone nigdy. Swoistym chlubnym wyjątkiem na mapie regionu chojnickiego jest artykuł Krzysztofa Szulczyka opublikowany w "Słowie Młodych" z lat 2011/2012, choć dotyczy on sąsiedniego powiatu tucholskiego ${ }^{35}$. Pewne aspekty odnoszące się do PPR w powiecie chojnickim porusza w swej książce Karolina Churska-Wołoszczak ${ }^{36}$. Zresztą zaprezentowane tutaj wyniki badań są tylko swoistym zarysem, gdyż zagadnienie PPR i rzeczywistości politycznej lat 1945-1948 w powiecie chojnickim zasługuje na osobną monografię.

W świetle zaprezentowanego stanu badań problemem badawczym staje się istotna luka poznawcza związana z funkcjonowaniem i rolą PPR w powiecie chojnickim w latach 1945-1948.

31 K. Ostrowski, W Polsce Ludowej i III Rzeczypospolitej, w: Dzieje Chojnic, red. K. Ostrowski, Chojnice 2010, s. 609-624.

32 Zob. M. Wałdoch, O chojnickim karnawale "Solidarności”. Kształtowanie się i rola nowego ruchu społecznego w warunkach lokalnych (1980-1981), Chojnice 2015, s. 15.

33 B. Głębowicz, op. cit., s. 271-272.

34 B. Dembowy, M. Romaniuk, Wstęp do inwentarza grupy zespołów Komitetów Miejskich i Powiatowych PPR woj. pomorskiego 1945-1948, s. 9, przechowywany w pracowni naukowej Archiwum Państwowego w Bydgoszczy.

35 K. Szulczyk, Polska Partia Robotnicza jako "światła przywódczyni narodu polskiego". Powiat tucholski w rękach komunistów (1945-1948), "Słowo Młodych" 2011-2012, 5, 16-23, s. $183-200$.

36 Zob. K. Churska-Wołoszczak, Referendum ludowe i wybory do Sejmu Ustawodawczego w województwie pomorskim (1946-1947), Bydgoszcz-Gdańsk 2014. 


\section{STRUKTURA I FUNKCJONOWANIE PARTII}

Wspomniana wcześniej „pierwsza trójka”, czyli J. Janek, M. Śmigielski i T. Rześniowiecki ${ }^{37}$, przybyli do Chojnic niedługo, bo ok. tydzień po zakończeniu walk Sowietów z wojskami niemieckimi o miasto. Można więc wskazać dokładną datę, kiedy PPR zaistniało w Chojnicach i na ziemi chojnickiej - 2 marca 1945 r. ${ }^{38}$ Była to trójka, która według historiografii stanowiła element siedmioosobowej grupy przybyłej do Chojnic z ramienia pomorskiej grupy operacyjnej KC PPR w Bydgoszczy. Ludzie ci, w związku z tym, że nie mieli wcześniej związków z Pomorzem, nazywani byli przez Pomorzan „lubliniakami”. Spośród wymienionej trójki M. Śmigielski był wcześniej szefem podobnej grupy operacyjnej w Grudziądzu, skąd przybył do Chojnic ${ }^{39}$. Pierwszym I sekretarzem PPR wyznaczony był na miasto Chojnice i powiat chojnicki M. Śmigielski, który funkcję swą pełnił tylko kilka miesięcy ${ }^{40}$, jego miejsce zajął Józef Rakoczy. Na początku września 1946 r. I sekretarzem PPR został Franciszek Musiał ${ }^{41}$, który był ogrodnikiem-traktorzystą pochodzącym z Ku$j^{42}{ }^{42}$ Z czasem rozdzielono funkcję I sekretarza PPR w Chojnicach od stanowiska I sekretarza PPR w powiecie chojnickim. Pierwsi sekretarze PPR w Chojnicach nie byli chojniczanami ani nie byli związani z ziemią chojnicką. Byli to typowi funkcjonariusze partyjni „przywiezieni w teczkach".

Zgodnie z instrukcją działania PPR na ziemi chojnickiej odbywały się konferencje powiatowe PPR. Konferencje powiatowe były najwyższą

37 W historiografii okresu PRL przyjmuje się, że T. Rześniowiecki, jako członek Stronnictwa Ludowego (SL), oraz Marian Śmigielski, wyznaczony przez KW PPR w Bydgoszczy do pełnienia funkcji I sekretarza PPR w Chojnicach, przybyli do Chojnic 28 II 1945 r. Wraz z nimi przybył do Chojnic komisarz ziemski Ludwik Strzelecki. Informacje te nie są jednak zgodne w świetle zachowanych dokumentów, z których wynika, że szefem Grupy Operacyjnej był por. Jan Janek z UB. Zob. B. Głębowicz, op. cit., s. 271-272.

38 AIPN By, WUSWB, WUBPB, sygn. IPN By 049/1, s. 6-7, Kierownik Grupy Operacyjnej Ministerstwa Bezpieczeństwa Publicznego na Chojnice Jan Janek do Wojewódzkiego Urzędu Bezpieczeństwa Publicznego w Bydgoszczy, Chojnice 9 III 1945.

39 R. Kozłowski, Polska, s. 60-65.

40 W późniejszym okresie M. Śmigielski przybywał do Chojnic z ramienia KW PPR z Bydgoszczy jako osoba, która była delegowana ze szczebla wojewódzkiego PPR dla rozwiązywania problemów i wspomagania lokalnego aktywu partyjnego. Zob. APB, KPPPRCh, sygn. 5, nlb., Protokół spisany na posiedzeniu Trójki Politycznej w dniu 9 III 1948 r. w Komitecie Powiatowym PPR w Chojnicach.

41 APB, KPPPRCh, sygn. 2, nlb., Protokół z III Zjazdu Konferencji Powiatowej PPR spisany w dniu 30 III 1947 r. w sali konferencyjnej Hotelu „Urbana” w Chojnicach.

42 K. Ostrowski, op. cit., s. 619. 
instancją partyjną $\mathrm{w}$ powiecie, wybierano na nich Komitet Powiatowy PPR i komisję rewizyjną $w$ trybie corocznym. Na posiedzeniach plenarnych KP wybierano I i II sekretarza KP na egzekutywę, a ta z kolei kierowała bieżąca polityką. Posiedzenia egzekutywy odbywały się raz na tydzień. KP PPR stanowił władzę wykonawczą. Całością prac kierował I sekretarz i II w sprawach organizacyjnych. Oprócz tego w strukturę partii $\mathrm{w}$ powiatach wchodzili instruktorzy, np. oświatowi, a także komisje KP, np. oświaty i kultury, samorządowa itd. Nadto powoływano Powiatową Komisję Kontroli Partyjnej. Jak wskazuje się w historiografii w początkowym etapie działalności PPR, aktywność partii skupiała się wokół I sekretarzy, z czasem dopiero przechodząc w tworzone instytucje partyjne $^{43}$. 21 sierpnia 1945 r. odbyła się II konferencja powiatowa PPR, w której udział wzięło 35 członków. W trakcie konferencji wyrażono radość z powstania Tymczasowego Rządu Jedności Narodowej oraz ze zwycięstwa "demokracji” również poza Polska, czyli w Anglii, gdzie wybory wygrała lewicowa Partia Pracy. Nadto delegat Komitetu Wojewódzkiego PPR wskazał, że: „Niełatwo było rozbić międzynarodowy faszyzm [...], ale przy silnej woli i nieustającej walce podołaliśmy zadaniom. Na błędach trzeba się uczyć, a więc i my idąc z prądem demokracji światowej, odłączać się od niej nie będziemy". Wezwano zebranych do czuwania nad porządkiem w państwie. M. Śmigielski podkreślał, „,[..] by partia wsiąkała systematycznie w masy i rozszerzała wpływ autorytetu i popularność, oraz demokratyzację od dołu". Zwracano uwagę na brak kadr dla administracji publicznej. W trakcie konferencji w wyborach tajnych wyłoniono Komitet Powiatowy PPR, w skład którego weszli: M. Śmigielski jako I sekretarz, Olszewski jako II sekretarz oraz członkowie komitetu: Oziemkiewicz, Kędzierski (Czersk), Śledź (Karsin), Gaidkowski (Czersk), Borowski (Chojnice), Maciopa (komendant Milicji Obywatelskiej) oraz Parczyński (komendant Powiatowego Urzędu Bezpieczeństwa Publicznego (PUBP) $)^{44}$. Partia była więc od samego swego zarania na ziemi chojnickiej umocowana $\mathrm{w}$ strukturach bezpieczeństwa państwa. Pomiędzy kwietniem a wrześniem 1945 r. liczba członków chojnickiego PPR wzrosła z 77 do $323^{45}$.

Poszukując wsparcia w masach, partia organizowała na Pomorzu uroczyste pogrzeby ofiar okupacji niemieckiej. Jak wskazuje się w literaturze,

\footnotetext{
43 B. Dembowy, M. Romaniuk, op. cit., s. 4-5.

44 APB, KPPPRCh, sygn. 11, nlb., Protokół z II Konferencji Powiatowej PPR w Chojnicach z dnia 21 VIII $1945 \mathrm{r}$.

45 R. Kozłowski, Polska, s. 100.
} 
w Chojnicach w takim pogrzebie brało udział około 10 tys. osób ${ }^{46}$. Manifestacyjny pogrzeb w Chojnicach odbył się 8 grudnia 1945 r. ${ }^{47}$

Przewagę elit partyjnych oraz dominację liderów lokalnego PPR wyraźnie widać w wyborach kandydatów na Zjazd Krajowy PPR w 1945 r., kiedy 15 października wybrano I sekretarza M. Śmigielskiego, członka komitetu powiatowego Śledzia oraz wiceburmistrza Chojnic Jana Fonsa. W trakcie dyskusji przedwyborczej referat wygłosił sekretarz KW PPR płk Antoni Alster ${ }^{48}$, który zaznaczył wagę braterstwa broni żołnierzy dywizji im. T. Kościuszki oraz Armii Czerwonej w bitwie pod Lenino, przechodząc następnie do oskarżeń wobec PSL, a szczególnie wobec S. Mikołajczyka, którego oskarżył o tworzenie Stronnictwa Ludowego. Jak argumentował: „Nie powinniśmy dopuścić tworzenia się nowych stronnictw rządów w Polsce, ponieważ rozdrobnienie partii szkodzi demokracji". M. Śmigielski z kolei zaznaczył trudności, jakie rodzą się dla PPR w związku z działalnością ludowców, wskazując nawet personalnie osobę odpowiedzialną za rozwój ludowców w byłym pośle Jóźwiku ${ }^{49}$

\footnotetext{
46 Ibidem, s. 94.

47 W. Buchholc, Chojnice w latach 1939-1945, Chojnice [b.d.w.], s. 81.

48 Antoni Alster (1903-1968), członek PPR, komunista i działacz KPP w okresie II RP.
} Po zakończeniu II wojny światowej I sekretarz KW PPR w Bydgoszczy, wspierający w PPS tzw. grupę jednolitofrontowa której przedstawiciele opowiadali się za jak najszybszym połączeniem z PPR. Zwalczał PSL. A. Alster był narodowości żydowskiej, przeszedł krótkoterminowy kurs w Związku Sowieckim w Międzynarodowej Szkole Leninowskiej w Moskwie. Zasiadał też w KC Komunistycznej Partii Zachodniej Ukrainy. W ZSRS pełnił również funkcję dyrektora drukarni. Był brany pod wzgląd do przerzutu do kraju w czasie okupacji niemieckiej. Kierował także Wydziałem Wojskowym KC PPR oraz był zastępca kierownika Wydziału Organizacyjnego KC. Nadto wchodził w skład Sekretariatu KC PPR obok Edwarda Ochaba. Funkcję I sekretarza KW PPR w Bydgoszczy objął po wygraniu wcześniejszego konfliktu z Kirylukiem, który piastował to stanowisko przed nim. Pełnił też funkcję zastępcy członka KC PPR. W późniejszym okresie A. Alster został wiceministrem spraw wewnętrznych. Zob. S. Błażejewski, J. Kutta, M. Romaniuk, Bydgoski słownik biograficzny, t. 6, Bydgoszcz 2000, s. 17-18; M. Szumiło, I sekretarze Komitetów Wojewódzkich PPR (1944-1948) - portret zbiorowy, „Dzieje Najnowsze” 2013, 45, 4, s. 43-59.

49 Józef Jóźwik (1885-1967), filozof, rolnik, poseł na Sejm Ustawodawczy 1919-1922, członek PSL „Piast”, w tym członek Rady Naczelnej i prezes Zarządu Wojewódzkiego. Od 1922 r. mieszkaniec Sławęcina k. Chojnic, gdzie prowadził gospodarstwo rolne. Aresztowany przez rządy sanacyjne w 1934 i 1938 r. Organizator strajku chłopskiego na Pomorzu w 1937 r. Uczestnik powstania warszawskiego. Po wojnie powrócił do Sławęcina i podjął działalność polityczną. W latach 1946-1947 był członkiem Rady Naczelnej PSL. W 1946 r. prezes Zarządu Wojewódzkiego PSL w Bydgoszczy. W wyborach 1947 r. wybrany na posła na Sejm Ustawodawczy, zrzekł się mandatu. Aresztowany w 1950 r. i więziony, wycofał się z życia politycznego. Wyprowadził się ze Sławęcina pod Poznań po pożarze domu. Rehabilitowany w 1957 r. Zob. Biblioteka Sejmowa, Baza „Parlamentarzyści polscy”, [hasło:] 
z Lipnic. Pojawił się w wyniku dyskusji problem zrównania wartości pracy robotników z wartością i wynagrodzeniem pracy urzędników ${ }^{50}$. Robotnicy bowiem narzekali na bardzo niskie uposażenie.

Na konferencji powiatowej w dniu 3 marca 1946 r. członek PPR reprezentujący władze wojewódzkie partii wyraził pogląd, zgodnie z którym społeczeństwo było wysoce zajęte polityką i uświadomione politycznie jak nigdy wcześniej. Jak mówił: „,...] ster rządu znajduje się w takich rękach, co słynny jest z czynu, a nie z nazwiska, jak to było po pierwszej wojnie światowej. Dlatego my dążymy do jedności narodu, a nie do rozbijania jednolitego frontu demokratycznego jak czyni P.S.L. popierany przez bande N.S.Z. i tak zwany rząd Londyński" ${ }^{51}$. Taka postawa miała prowadzić do osiągnięcia sytuacji, w której Polska stanie się „krajem o demokracji ludowej" 52 .

Istotnym zagadnieniem stała się rekrutacja kolejnych członków oraz dalsze podnoszenie świadomości politycznej obecnych już działaczy. Zakładano konieczność dokooptowania do partii pracowników instytucji publicznych, bo jak mówiono: „[...] wszak my jesteśmy Partia żelazna”. Wskazano także na konieczność organizacji powiatowego sądu partyjnego. W trakcie konferencji wybrano nowe władze Komitetu Powiatowego PPR, I sekretarzem został Jan Olszewski, II sekretarzem Jan Maciopa, a członkami komitetu powiatowego: Tadeusz Roszkowski, Antoni Kędzierski, Edmund Piekarski, Henryk Remisz, Maksymilian Krüger, Jan Ochoja oraz Franciszek Klaman ${ }^{53}$. W tamtym okresie (marzec 1946 r.) PPR liczył 475 członków zorganizowanych w 41 komórek $^{54}$. Komitet Powiatowy PPR w pierwszym roku działalności składał się z 11 członków. Pod względem struktury zawodowej i społecznej zasiadało w nim: 9 robotników, 1 chłop i 1 inteligent. Partia notowała niewielki napływ nowych członków, gdyż pomiędzy 3 a 30 marca $1946 \mathrm{r}$. ich liczba w powiecie wzrosła z 475 do 495. Najmniejszą aktywność w ramach PPR notowano w gminach:

Jóźwik Józef, https://bs.sejm.gov.pl/F?func=find-b\&request=000002135\&find_code=SYS\&local_base=ARS10 [dostęp: 6 I 2020]. J. Jóźwik był też jednym z nielicznych wyborców po wyborach do Sejmu Ustawodawczego w styczniu 1947 r., który złożył protest przeciwko ważności wyborów w okręgu wyborczym nr 25 Bydgoszcz do Sądu Najwyższego w Łodzi. Protest dotyczył między innymi niedopuszczenia do składu komisji wyborczych przedstawicieli PSL, zob. K. Churska-Wołoszczak, op. cit., s. 259-265.

50 APB, KPPPRCh, sygn. 1, nlb., Protokół z Konferencji Powiatowej PPR celem wyboru kandydatów na Zjazd Krajowy odbytej w Chojnicach dnia 15 X 1945 r.

51 Ibidem, nlb., Protokół z Konferencji Powiatowej PPR z 3 III 1946 r. wraz z wyborami nowego Komitetu Powiatowego.

52 Ibidem.

53 Ibidem.

54 Ibidem. 
Brusy, Leśno, Lipnica i Borowy Młyn, więc na ziemi kaszubskiej. Partia obudowywała się organizacjami satelickimi, szczególnie młodzieżowymi, takimi jak Związek Walki Młodych, do której przynależało 128 członków w marcu 1946 r. oraz Towarzystwo Uniwersytetu Robotniczego (66 członków). Związek Młodzieży Wiejskiej RP „Wici” szacowano na 30 członków. PPS, z którym współpraca układała się poprawnie, określano na 250 członków, a Stronnictwo Ludowe (SL), z którego elitami współpracy nie widziano poprawnie przez wzgląd na relacje z PSL, na 157 członków. Obserwowano zaś niewielką aktywność Stronnictwa Demokratycznego (SD), określając je na ok. 30 członków i przypisywano tej partii „tendencje endeckie”. PSL określano jako „oficjalnie słabe”. Przez wzgląd na postawę i wypowiedzi J. Jóźwika lokalne elity PPR uważały, że „,[...] współpraca została przekreślona" z ludowcami Mikołajczyka, ponadto zauważano, iż: „Poszczególni członkowie działacze, prowadzą propagandę anty-demokratyczną i anty-sowiecką". Szacowano, że PSL w tamtym czasie miał ok. 20 członków na terenie powiatu. Na wiosnę 1946 r. określano sytuację polityczną w następujący sposób: „Społeczeństwo tutejsze w większości bierne, nieuświadomione, przepojone duchem przedwrześniowym, zgermanizowane, natomiast kierownicze stanowiska obsadzone różnymi elementami reakcyjnymi karierowiczami, często swym postępowaniem demoralizują całe społeczeństwo. Wpływ partii znikomy na czynniki rządzące $^{\prime \prime 55}$. PPR doskwierało też w powiecie już po wyborach 1947 r. to, że nie posiadała $w$ swych szeregach przedstawicieli lokalnej inteligencji. Problem ten wynikał zarówno z profilu partii i jej początkowego ukierunkowania się na umacnianie się przede wszystkim w środowiskach robotniczych, jak i, co podkreślał I sekretarz PPR F. Musiał, z faktu, że „,[...] pow. chojnicki był już przed wojną kolebką śmierdzącej reakcji" ${ }^{56}$. W czasie gdy 21 listopada 1948 r. odbyła się ostatnia konferencja powiatowa PPR, wśród 106 delegatów było 94 osób z wykształceniem powszechnym, 12 ze średnim i ani jednej osoby z wykształceniem wyższym ${ }^{57}$.

55 Ibidem, nlb., Sprawozdanie roczne z działalności Polskiej Partii Robotniczej, Komitetu Powiatowego w powiecie chojnickim, Chojnice, 30 III 1946.

56 APB, KPPPRCh, sygn. 2, nlb., Protokół z III Zjazdu Konferencji Powiatowej PPR spisany w dniu 30 III 1947 r. w sali konferencyjnej Hotelu „Urbana” w Chojnicach.

57 APB, KPPPRCh, sygn. 3, nlb., PPR Zestawienie z wykazu imiennego delegatów na konferencję partyjną w dniu 21 XI $1948 \mathrm{r}$. 


\section{SYSTEM PARTYJNY NA PROWINCJI}

Zgodnie z narzuconym przez J. Stalina modelem relacji pomiędzy partiami politycznymi w Polsce, czyli wymuszonym systemem partyjnym, pomiędzy którymi wykluczono otwartą rywalizację polityczną na rzecz uzgadniania stanowiska stronnictw politycznych, najczęściej sprowadzały się one do przyjmowania stanowiska narzucanego przez PPR ${ }^{58}$. W marcu 1945 r., zaraz po powołaniu do życia PPR w powiecie chojnickim, partia ta stała się nieformalnym sitem rekrutacji przyszłych funkcjonariuszy aparatu bezpieczeństwa na podległym terenie ${ }^{59}$. Nieco ponad miesiąc po powołaniu PPR odbyło się pierwsze spotkanie założycielskie powiatowego PPS w dniu 30 kwietnia $1945 \mathrm{r}^{60}$ i od tego momentu partie te pozostawały ze sobą w stałej interakcji. W związku z tym od 2 października 1945 r. odbywały się posiedzenia Komisji Porozumiewawczej w Chojnicach, głównie brały w nich udział PPR i PPS powiatu chojnickiego. Początkowo przedmiotami posiedzeń były kwestie zarzutów o współpracę z Niemcami w czasie okupacji niektórych aktywistów PPS. Wskazywano także problemy, z którymi PPR nie radził sobie i szukał poparcia w PPS, choćby takie jak to, „[...] że nauczycielstwo w Chojnicach nie stoi na wysokości swego zadania, ponieważ młodzież szkolna szczególnie harcerska przy każdej okazji występuje wrogo przeciwko socjalizmowi i organizacjom T.U.R-u i Walki Młodych [...]. Referujący proponował, by Partie same organizowały szkoły w myśl zasad socjalizmu i postępu" ${ }^{\prime 61}$. Podjęto też decyzje, które były jawną represją wobec nauczycieli, bowiem zdecydowano o zwołaniu zebrania kierowników chojnickich szkół, aby subordynować ich, nauczycieli i młodzież, zgodnie z głoszonymi ideami PPR ${ }^{62}$. M. Śmigielski wskazywał na nagły przy-

5824 XI 1944 r. powołano Centralną Komisję Porozumiewawczą Stronnictw Demokratycznych (CKSDP), na platformie której dokonano eliminacji wolnej gry politycznej, wymuszając konsultacje międzypartyjne. Zob. A.L. Sowa, Historia polityczna Polski 1944-1991, Kraków 2011, s. 30.

59 AIPN By, WUSWB, WUBPB, sygn. IPN By 049/1, s. 2-3, Sprawozdanie dekadowe Kierownika Powiatowego Urzędu Bezpieczeństwa Publicznego do Szefa Wojewódzkiego Urzędu Bezpieczeństwa Publicznego w Bydgoszczy z 1945 r., Chojnice, 24 III 1945.

60 Pierwszym przewodniczącym powiatowego PPS został Jan Zawieja, Władysław Jaworski objął stanowisko sekretarza, a Feliks Wolski skarbnika. APB, Powiatowy Komitet Polskiej Partii Socjalistycznej w Chojnicach [dalej: PKPPSCh], sygn. 1, nlb., Protokół z pierwszego konstytuującego się zebrania Komitetu Polskiej Partii Socjalistycznej w Chojnicach, Chojnice, 30 IV 1945.

61 APB, KPPPRCh, sygn. 5, nlb., Protokół w dniu 2 X 1945 r. Komisji Porozumiewawczej PPS i PPR w Chojnicach.

62 Ibidem. 
rost majątku starosty chojnickiego i proponował sprawdzenie stanu posiadania. Krytykowano postawy prezesa Powiatowej Rady Narodowej oraz łączenie przez niego zbyt wielu funkcji i sprzyjanie PSL. Zdecydowano też wstrzymać wniosek o odwołanie burmistrza Chojnic, bowiem ten wykazał ostatecznie aktywność partyjną w ramach PPR. Deklarowano jednolity front działań PPR i PPS na terenie powiatu chojnickie$\mathrm{go}^{63}$. Ten front $\mathrm{z}$ PPS nie był jednak spójny. Jak podkreślał w swych sprawozdaniach sekretarz PPS w Chojnicach Wojciech Batkowski: ,[...] głosi się współpracę obubratniej partii P.P.S. i P.P.R. a defakto, utrudnia się te współpracę $[. . .]^{\prime 64}$. Podkreślano też, że „[...] PPR stosuje robotę rozbijacką pośród naszych członków" ${ }^{\prime 65}$. Sytuacja relacji z PPR zaczęła się poprawiać z PPS dopiero od marca 1948 r. ${ }^{66}$

Sprawa młodych wracała na kolejnych spotkaniach międzypartyjnych, kiedy w kwietniu 1946 r. ppor. Sarna, oficer polityczny, podkreślał różnice, jakie występują $\mathrm{w}$ poziomie postaw i świadomości politycznej wśród młodzieży Polski północnej, a Polski południowej i centralnej, gdzie bliższa ona była wzorcom komunistycznym. Zarzucano miejscowej ludności wysoki stopień germanizacji. Tropiono też reakcyjność lokalnych $w_{\mathfrak{~} ł a d z}{ }^{67}$. Latem 1946 r. odbyło się posiedzenie Komisji Porozumiewawczej, w której udział wzięli przedstawiciele poza dwiema wyżej wspomnianymi partiami: SD (Larski i Zaufały), SL (Gierszewski), SP (Zaremba) i pracownik Powiatowego Oddziału Informacji i Propagandy Mrówczyński. Podkreślano drożyznę artykułów i negatywny wpływ nielegalnego handlu. Po ponad roku od zakończenia wojny ponaglano władze powiatowe i aparatu bezpieczeństwa, konkludując: „[...] gdzie jeszcze są niemcy takowych usunąć a dane obsadzić Polakami [...] spowodować aby ob. Starostwa i Urząd Bezpieczeństwa zajęli się energiczniej za sprawę wysiedlenia Niemców z gospodarstw" ${ }^{\prime 68}$. Dyskutowano także zmianę na stanowisku wójta Konarzyn, proponując obsadzenie stanowiska członkiem PPR, w podobny sposób rozwiązano „problem” wójta Brus, którego zastąpiono uzgodnionym na Komitecie Porozumiewawczym członkiem

\footnotetext{
63 Ibidem.

64 APB, PKPPSCh, sygn. 1, nlb., Sprawozdanie Sekretarza Powiatowego Komitetu PPS w Chojnicach za czas od 16 II do 1 III 1947 r.

65 Ibidem, nlb., Sprawozdanie Sekretarza Powiatowego PPS w Chojnicach za miesiąc kwiecień $1947 \mathrm{r}$.

66 Ibidem, nlb., Sprawozdanie Powiatowego Komitetu PPS w Chojnicach za miesiąc marzec $1948 \mathrm{r}$.

67 APB, KPPPRCh, sygn. 5, nlb., Protokół z posiedzenia Nadzwyczajnego przedstawiciela Partii Politycznych z dnia 27 IV 1946 r.

68 Ibidem, nlb., Protokół z zebrania Międzypartyjnej Komisji Porozumiewawczej z dnia 3 VIII 1946 r.
} 
PPS. Niemniej między partiami dochodziło do starć w kwestii kandydatów na wójtów, ale PPR rozwiązywała je groźbą eskalacji napięcia. Powracała też sprawa konieczności odwołania ze stanowiska burmistrza Chojnic $^{69}$. Również pod koniec 1946 r. na posiedzeniu Komitetu Porozumiewawczego rozmawiano o przydziałach na stanowiska $w$ administracji „samorządowej" ${ }^{70}$. W gronie PPR-PPS decydowano również o obsadzie stanowiska starosty chojnickiego oraz rad narodowych, wysuwając najczęściej kandydatów według klucza: PPR-PPS; PPS-PPR. Wskazywano także na próby podniesienia krytyki ze strony Kościoła katolickiego, zaznaczając jednak, że nawet listy biskupie przechodzą cenzurę, więc też: ,[...] nic nadzwyczajnego nie mogło w nim byćc ${ }^{\prime \prime 1}$. Jednak te same listy stały się wyrazem troski I sekretarza PPR w Chojnicach Musiała, bowiem pisał do A. Alstera: „[...] po ostatnich odczytanych listach pasterskich $\mathrm{z}$ ambon kościelnych $\mathrm{t} / \mathrm{j} \mathrm{w}$ niedzielę 20 . b. m. ludność cała zajęta jest rozumowaniem że muszą $\mathrm{w}$ przyszłych wyborach głosować za ludźmi kształconymi a nie komunistami [...]"72.

Podejmowano także na takich spotkaniach decyzje o zleceniu PUBP w Chojnicach weryfikacji ławników sądowych poprzez zdobycie informacji o opinii środowiskowej na ich temat ${ }^{73}$. Podejmowano też decyzje o konieczności rozwijania Ochotniczych Rezerw Milicji (ORMO) ${ }^{74}$. Zresztą funkcjonariusze UB, jak komendant PUBP Blachewicz, brali udział w wybranych spotkaniach PPR-PPS. W związku ze zwycięstwem wyborczym z 19 stycznia 1947 r. zaostrzała się retoryka komunistów. W ocenie I sekretarza KP PPR Musiała: „[...] reakcja odniosła druzgocącą klęskę w dniu 19 stycznia b. r., a że odniosła klęskę to są zasługi dwubratnich partii PPR i PPS i mimo zwycięstwa jakie odnieśliśmy to tem więcej musimy jeszcze pracy włożyć by reakcję zniszczyć i to szczególnie w terenie" $^{\prime 75}$. Komuniści nadal wyrażali niezadowolenie z pracowników administracji „samorządowej”, wskazując na dalszą konieczność rotacji kadr. Ponadto obrano kierunek ograniczania dostępu do zatrudnienia: „Co do

\footnotetext{
69 Ibidem.

70 Ibidem, nlb., Protokoły z posiedzenia komisji porozumiewawczej Partii Demokratycznych w Czersku w dniu 15 X 1946 r.

71 Ibidem, nlb., Protokół z wspólnego posiedzenia Komitetów PPR i PPS w Chojnicach, Chojnice, 22 X 1946.

72 APB, KPPPRCh, sygn. 7, nlb., PPR w Chojnicach do KW PPR w Bydgoszczy, Chojnice, $21 \times 1946$.

73 Ibidem.

74 APB, KPPPRCh, sygn. 5, nlb., Protokół ze wspólnego posiedzenia Kom. PPR i PPS w Chojnicach, Chojnice, 25 XI 1946.

75 Ibidem, nlb., Protokół Międzypartyjnej Komisji Porozumiewawczej, Chojnice, 21 II 1947.
} 
sprawy bezrobotnych naszych, towarzyszy, zwrócił tow. Piotrowski by uchwalali rezolucje by wywrzeć na kierownikach fabryk by przyjmowali ludzi tylko partyjnych"76. Szef UB zaznaczył, że gdy przybył do Chojnic, niemal wszyscy funkcjonariusze UB byli bezpartyjni, a wszyscy są już $\mathrm{w}$ partii. Konfrontowano się też z poważnym problemem żądania zwrotu mienia przez osoby rehabilitowane, którym odebrano mienie i przyznano je najczęściej ludności przesiedlonej ${ }^{77}$.

Spotkania między partiami PPR i PPS były też okazją do wyprowadzania ataku i podporządkowywania sobie działań PPS, choć zdarzało się, że poszczególni członkowie PPS, jak W. Błatkowski, występowali $\mathrm{w}$ obronie represjonowanych przez UB działaczy. Na posiedzeniu 29 maja 1947 r. w sekretariacie PPS wziął on w obronę kierowaną przez siebie $\mathrm{w}$ powiecie organizację, w ten sposób, iż: „[...] zarzucił że organa bezpieczeństwa niesłusznie maltretują członków PPS"78. Szef UB oczywiście te oskarżenia odrzucał.

Partie podkreślały też konieczność pełnej mobilizacji, aby zdominować w wyborach Rady Zakładowe chojnickich zakładów pracy. Przewijał się temat obsady stanowisk w lokalnym "samorządzie", PPR i PPS dążyły między innymi w 1947 r. do odwołania wiceburmistrza Czerska Sobczaka, którego uważali za reakcjonistę. Relacje PPR z partiami „wrogimi" były regulowane poprzez tworzenie Komisji Mediacyjnych i taka komisja istniała w $1947 \mathrm{r}$. pomiędzy PPR i SD w powiecie chojnickim ${ }^{79}$. Najsłabsze struktury PPR i PPS, jako partie robotnicze, posiadały w powiecie chojnickim zarówno w gminie Brusy, jak i w gminie wiejskiej Chojnice, gdzie gminne rady narodowe znajdowały się w rękach SL, które określano jako „reakcyjne elementy SL stosujące robotę na system Mikołajczykowski" ${ }^{80}$. Chojniccy komuniści wprowadzili na jednej z konferencji międzypartyjnej interesujące rozróżnienie na: socjalizm odstępny oraz na socjalizm marksistowski. Nie dając jednak szerszego wyjaśnienia tych pojęć. Jednak walka z reakcją była wciąż obecna $\mathrm{w}$ deklaracjach członków PPR, takich jak Malatyński. W związku z tym postulowano walkę z wrogiem wewnątrzpartyjnym ${ }^{81}$. Dowodem dominującej i wzrastającej roli PPR w powiecie chojnickim może być przebieg posiedzenia

\footnotetext{
76 Ibidem.

77 Ibidem.

78 Ibidem, nlb., Protokół z posiedzenia Komisji Porozumiewawczej PPR i PPS odbytej w dniu 29 V 1947 r. w sekretariacie PPS, Chojnice.

79 Ibidem.

80 Ibidem, nlb., Protokół z posiedzenia szóstki współdziałania PPR-PPS z dnia 25 VIII 1948 r. odbytego w Sekretariacie PPR w Chojnicach.

81 Ibidem, nlb., Protokół z posiedzenia aktywu PPR i PPS odbytego w dniu 13 VIII 1947 r. w Chojnicach w lokalu Komitetu Powiatowego PPR, Chojnice, 25 X 1947.
} 
z 22 stycznia 1948 r. pomiędzy władzami PPR i SL, które zostało zmuszone do uzgadniania swej działalności w terenie. Członkom SL zarzucano np. że „,[...] wyrażają się nieprzychylnie co do członków PPR, wyrażają się nieraz, że jesteście komunistami, i na wsi nie powinien istnieć PPR tylko samo SL, bo wieś należy jako chłopstwo wyłącznie dla SL-u" ${ }^{\prime 2}$. Władze PPR-u były niezwykle czułe na publiczne oskarżenia o komunizm i tępiły takie oceny w zarodku. Poza organizacją spotkań międzypartyjnych w bardzo konfliktowych sprawach spotykali się tylko szefowie lokalnych struktur PPR, PPS i SL ${ }^{83}$.

Z czasem przymusowa współpraca polityczna pomiędzy PPR i PPS została zacieśniona poprzez powołanie tzw. szóstki politycznej, w skład której weszli z ramienia PPR: F. Musiał, Henryk Dereszyński, Roman Majewski, natomiast PPS delegowało: W. Batkowskiego, Władysława Jaworskiego i Władysława Synaka ${ }^{84}$. Podobne „szóstki” PPR-PPS powołano $\mathrm{w}$ gminach powiatu chojnickiego ${ }^{85}$. Wzburzenie $\mathrm{w}$ działaczach dwóch partii wzbudziło w połowie 1948 r. stanowisko papieża Piusa XII w sprawie polskich granic zachodnich ${ }^{86}$. Przy tym szef lokalnych struktur PPR przyznawał sobie prawo określania tego, kim są wrogowie i przeciwnicy partii ${ }^{87}$. Ze stanowiska patrymonialnego oceniano inne ugrupowania i stronnictwa, i tak SL oceniano relatywnie pozytywnie, choć wskazywano, że $\mathrm{w}$ tej formacji $\mathrm{w}$ powiecie są jednostki reakcyjne, które nie miały chłopskiego pochodzenia ${ }^{88}$. Konflikt z SL w powiecie był wypadkową między innymi rozgrywki o obsadzenie wójta Brus, którego wskazywała gminna rada narodowa, a w której przewagę miało SL, niegodzące się w sierpniu 1948 r. na obsadzenie kandydata PPR. Próbując zapobiec dalszemu oporowi członków SL w Brusach, władze PPR z Chojnic naciskały na wywarcie presji na struktury SL poprzez władze wojewódzkie, tak aby

82 Ibidem, nlb., Protokół z posiedzenia Trójki Aktywnej PPR i SL odbytej w dniu 20 I 1948 r. w sekretariacie PPR w Chojnicach.

83 Ibidem, nlb., Protokół spisany na posiedzeniu Trójki Politycznej w dniu 9 III 1948 r. w Komitecie Powiatowym PPR w Chojnicach.

84 Ibidem, nlb., Protokół z posiedzenia egzekutywy PPR i PPS w dniu 11 IV 1945 r., Chojnice.

85 Ibidem, nlb., Protokół z posiedzenia Powiatowej szóstki współdziałania w Chojnicach, Chojnice, 11 VI 1948.

86 Ibidem, nlb., Protokół wspólnego zebrania sekretarzy kół obu partii PPR-PPS miasta Chojnice, 1 VI 1948.

87 Ibidem, nlb., Protokół z posiedzenia Komisji Współdziałania odbytej w dniu 10 XI 1948 r. w sekretariacie PPR, Chojnice, 11 XI 1948.

88 Ibidem, nlb., Sprawozdanie współpracy PPR i SL, Chojnice, 19 IX 1947. 
nie stawiały oporu w obsadzeniu stanowiska wójta kandydatem z PPR ${ }^{89}$. Negatywną ocenę wystawiono współpracy ze Stronnictwem Pracy (SP), którego aktywność określono na znikomą, zaś profil działań jako obronę Kościoła i wartości chrześcijańskich. Z kolei społeczną bazę SD wskazano w bogatych kupcach i przedsiębiorcach, którzy wykazywali postawy konserwatywne i chrześcijańskie. W ogólnej ocenie postawę SD oceniano, pomimo istnienia relacji i wspólnych posiedzeń z PPR, na wroga a części członków na antydemokratyczną. We wrześniu 1947 r. oceniano, że PSL Nowe Wyzwolenie przestało funkcjonować na terenie powiatu ${ }^{90}$. Członków ugrupowań spoza Bloku Demokratycznego surowo ścigano za najmniejsze przewinienie rzeczywiste bądź domniemane, ale łamanie prawa przez członków PPR, nawet sekretarzy gminnych partii, było przez PPR tolerowane. Nawet sekretarz powiatowy F. Musiał wstawiał się u A. Alstera o zwolnienie z UB Franciszka Reszki i Teofila Zakrzewskiego z Rytla w kwietniu 1947 r., którzy przyłapani zostali na kłusownictwie z wykorzystaniem nielegalnej broni. Partia w takich przypadkach decydowała się o nakazaniu swoim członkom łamiącym prawo „natychmiastowe opuszczenie terenu" i przenosiła ich $\mathrm{w}$ inne miejsca. Wspierając zatrzymanych przez UB na kłusownictwie i wykorzystaniu nielegalnej broni, I sekretarz PPR w powiecie pisał do A. Alstera: „wymienieni swą pracą i poświęceniem zasłużyli pod każdym względem na udzielenie im poparcia i interwencję w ich sprawie" ${ }^{\prime 1}$. Z drugiej strony tylko zakłady, których załogi były w PPR, miały szansę na dostęp do najnowszych urządzeń i szansę na rozwój. Tak było w przypadku chojnickiej garbarni. Wstawiając się za inwestycją w rozbudowę zakładu, I sekretarz KP PPR pisał: „Zaznaczamy, że cały personel garbarni wraz z kierownictwem są członkami Polskiej Partii Robotniczej" ${ }^{\prime 92}$. Już po skonsolidowaniu swej władzy PPR był na tyle silny w powiecie i Chojnicach, że mógł występować nawet przeciwko znanym działaczom i propagatorom kultury jak Albin Makowski, którego lokalny PPR uznał za wroga i żądał usunięcia go ze stanowisk pełnionych $w$ instytucjach kultury gminnej ${ }^{93}$. Pomimo tego ani w powiecie, ani w jego stolicy PPR, co przyznawały lokalne władze w partii, nie stała się

\footnotetext{
89 APB, KPPPRCh, sygn. 7, nlb., PPR w Chojnicach do KW PPR w Bydgoszczy, Chojnice, 1 IX 1948.

90 APB, KPPPRCh, sygn. 5, nlb., Sprawozdanie o działalności partii politycznych SP SD PSL N. W., Chojnice, 19 IX 1947.

91 APB, KPPPRCh, sygn. 7, nlb., PPR w Chojnicach do KW PPR w Bydgoszczy, Chojnice, 9 IV 1947.

92 Ibidem, nlb., KP PPR w Chojnicach do KW PPR Wydział Przemysłowy w Bydgoszczy, Chojnice, 11 VI 1948.

93 Ibidem, nlb., Komisja Administracyjno-Samorządowa Komitetu Powiatowego P. P. R. do KW PPR Wydział Administracyjno-Samorządowy w Bydgoszczy, Chojnice, 24 IV 1948.
} 
organizacją masowa, nadal były grupy społeczne i zawodowe, do których partia miała utrudniony dostęp. Taki stan rzeczy komentowano latem 1948 r. w następujący sposób: „,[...] na odcinku rzemiosła partia nasza jest bardzo słabo reprezentowana" ${ }^{\prime 4}$. PPR do czasu zjednoczenia z PPS miał poważny problem $\mathrm{z}$ radami zakładowymi, gdzie $\mathrm{w}$ większości przewagę mieli członkowie PPS. PPR oskarżała władających radami zakładowymi o wrogie nastawienie do ustroju, a dyrekcję, w której widziano przedwojennych urzędników, o tworzenie barier, a nawet bezpodstawne zwalnianie członków PPR ${ }^{95}$. Twierdzono też, że na ziemi chojnickiej robotnicy wykazywali stosunek krytyczny wobec władzy ludowej , [...] na wskutek wpływu kleru na psychikę robotnika" ${ }^{96}$. Dodatkowo oskarżano pozostałych jeszcze na rynku przedsiębiorców sektora prywatnego o to, że: „[...] celowo podwyższa zarobki by wywołać ferment wśród robotników pracujących na zakładach państwowych" ${ }^{\prime 97}$. Kiedy w 1947 r. PPR w dużej mierze poradziła sobie $\mathrm{z}$ opozycją i działaczami opozycji $\mathrm{w}$ powiecie chojnickim, zaczęto szukać wroga wewnętrznego. Pierwszym tego przejawem była konferencja powiatowa PPR w marcu 1947 r., kiedy padały wzajemne oskarżenia o odchylenia i rozpoczęto polowanie na „swołocz wewnątrzpartyjną" ${ }^{\prime \prime 8}$. W tym samym czasie struktury partii znacznie się rozrosły, bowiem w maju 1946 r. do PPR należało 546 członków w 46 kołach i 2 komitetach miejskich, a w kwietniu 1947 r. do partii należało już 1715 osób zorganizowanych w 61 kół i 2 komitety miejskie, 4 gminne i 1 komitet kolejowy ${ }^{99}$. Liczebność partii 12 czerwca 1948 r. wynosiła 2159 osób ${ }^{100}$. Dodatkowo rozwijano działalność organizacji satelickich, takich jak Towarzystwo Przyjaźni Polsko-Radzieckiej (TPPR), która skupiała 950 osób pod koniec listopada 1948 r. TPPR zajmowało się głównie szerzeniem wiedzy o „osiągnięciach ludów Z. S. R. R." ${ }^{101}$. Zaś do największych organizacji poza PPR należała Służba Polsce, która skupiała w tym samym

94 Ibidem, nlb., KP PPR w Chojnicach do KW PPR w Bydgoszczy, Chojnice, 17 VII 1948.

95 APB, KPPPRCh, sygn. 20, nlb., Sprawozdanie z Wydziału Zawodowego przy Pow. Kom. P.P.R. w Chojnicach za miesiąc czerwiec 1947 r., Chojnice, 20 VI 1947.

96 Ibidem, nlb., Sprawozdanie Wydz. Zawodowego przy KP PPR w Chojnicach za okres od 1 VII do 15 IX 1948 r., Chojnice, 1 X 1948.

97 Ibidem.

98 APB, KPPPRCh, sygn. 2, nlb., Protokół z III Zjazdu Konferencji Powiatowej PPR spisany w dniu 30 III 1947 r. w sali konferencyjnej Hotelu „Urbana” w Chojnicach.

99 Ibidem, nlb., Wykaz ilościowy członków w poszczególnych miesiącach oraz ilość komitetów w powiecie chojnickim (maj 1946 - kwiecień 1947).

100 APB, KPPPRCh, sygn. 24, nlb., Zestawienie.

101 APB, KPPPRCh, sygn. 3, nlb., Sprawozdanie z rocznej pracy Powiatowego Komitetu PPR w Chojnicach, Chojnice, 18 XI 1948. 
czasie 2330 członków. Głównym zajęciem dla tej organizacji były prace w polu i przy żniwach oraz rekrutowanie do nich młodzieży szkolnej ${ }^{102}$.

\section{STOSUNEK WOBEC ZBROJNEGO PODZIEMIA NIEPODLEGŁOŚCIOWEGO}

PPR w powiecie chojnickim spotkało się z, jak sami członkowie partii raportowali, oporem społeczeństwa przed wstępowaniem do partii w okresie 1945/1946 w związku ze strachem przed działalnością polskiego podziemia niepodległościowego, czyli według nomenklatury komunistów „band leśnych". Jak pisano do A. Alstera w październiku $1946 \mathrm{r}$. z Chojnic: „Między innymi nasi niejedni tow. aktywiści zostali pobici a niektórzy okradzeni przez oprychów z lasu i z tego powodu niejedni tow. zwrócili nam swe legitymacje [...] żądają natychmiastowego wystąpienia z P.P.R-u i wyłudzają nieraz ostatnie pieniądze"103. Jak podawano 16 października 1946 r., żołnierze podziemia byli w Charzykowych, gdzie członkowi PPR Nasielskiemu zagrożono śmiercią jeśli nie wystąpi $\mathrm{z}$ partii. 18 października tego samego roku byli w gromadzie Mokre u innego członka partii - Piankowskiego, a 19 października w Ciecholewach u Jana Ochojny i Lachmana, również żądali wystąpienia z PPR pod groźbą śmierci. 20 października 50-osobowy oddział żołnierzy podziemia pobił we wsi Ostrowite koło Chojnic członka PPR Brunkę, oddziały te były też we wsi Sławęcin. Jak pisano - najwierniejsi towarzysze zmuszeni byli przez żołnierzy podziemia do spania w nocy po stodołach i chlewach, żeby nie dostać się w ręce podziemia. Pierwszy sekretarz PPR F. Musiał pisał w kontekście tych zdarzeń do A. Alstera: „,[...] uważam, że powiatem chojnickim trzeba byłoby specjalnie się zająć $[. . .]^{\prime \prime 104}$. F. Musiała irytowała też postawa mieszkańców powiatu chojnickiego, wyraził tę irytację w ten sposób: „,[...] teren powiatu chojnickiego to same lasy i dlatego też trudno jest wpaść na trop bandy, co w niejednych wypadkach ludność miejscowa na pewno współpracuje $\mathrm{z}$ bandami dopomagając im w wyżywieniu i ukryciu oraz pewnymi nieraz informacjami"105, i podkreślając beznadziejne położenie oraz motywując prośbę o zakup samochodów dla UB, aby ta likwidowała polskie podziemie niepodległościowe. Pisał: „Bo gdy władze wyższe nie dopomogą nam w tym terenie likwidując bandy to

\footnotetext{
102 Ibidem.

103 APB, KPPPRCh, sygn. 7, nlb., PPR w Chojnicach do KW PPR w Bydgoszczy, Chojnice, $21 \times 1946$.

104 Ibidem.

105 Ibidem.
} 
na pewno nasza praca będzie bezowocna"106. W sierpniu 1948 r. PPR rekomendowała na stanowisko wójta Karsina Leona Czucha, który jak pisali działacze PPR, otrzymał wcześniej wyrok śmierci od żołnierzy podziemia i był zmuszony ukrywać się w Gdyni. Aktywiści PPR w sierpniu 1948 r. twierdzili, że z ich szeregów na terenie powiatu zginęło zabitych przez podziemie niepodległościowe dwóch członków partii ${ }^{107}$. W marcu 1947 r. I sekretarz PPR w czasie konferencji KP PPR wyraził swoją radość ze zwalczenia zbrojnego podziemia niepodległościowego na terenie powiatu chojnickiego następującymi słowami: „Po ostatniej klęsce zadanej bandom leśnym przez dzielne organa naszego Bezpieczeństwa i Milicji oraz potwierdzeniu że P.S.L. zasilało bandy swoimi członkami społeczeństwo pow. chojnickiego zrozumiało że tylko P.P.R. daje gwarancję pokoju i bezpieczeństwa w odrodzonej Polsce"108.

\section{CENTRALNY DOM PARTII}

Jedną z głównych inicjatyw struktur PPR w powiecie chojnickim była zbiórka na tzw. Dom Partii. Wśród grup zawodowych i środowisk składających się na budowę „Domu Partii” w powiecie chojnickim, według sprawozdania z 5 czerwca 1948 r., najwięcej pieniędzy na zbiórkę wpłacili funkcjonariusze PUBP, przekazując 358500 zł z ogólnie zebranej kwoty $1316950 \mathrm{zł} \mathrm{w}$ Chojnicach. Na drugim miejscu plasowało się środowisko rzemieślnicze z kwotą $180500 \mathrm{zl}$, a na trzecim Milicja Obywatelska ${ }^{109}$. Poza Chojnicami na terenie powiatu na dom partii zebrano nieco ponad $700000 \mathrm{z}^{110}$. Jednocześnie Egzekutywa KP PPR Chojnice mobilizowała swoich członków w październiku 1948 r. do wytężonej pracy na rzecz zbiórki środków poprzez objazd "trójek partyjnych" w kołach partii na terenie gmin. I tak np. tow. Malatyński i II sekretarz tow. Dereszyński odpowiedzialni byli za wizytę dwa razy w miesiącu Brus i Leśna ${ }^{111}$. Ówczesne zbiórki, również z powiatu chojnickiego, na rzecz budowy Centralnego Domu Partii przekazane zostały na rzecz nowego gmachu Komitetu

\footnotetext{
106 Ibidem.

107 APB, KPPPRCh, sygn. 5, nlb., Sprawozdanie o działalności partii politycznych SP SD PSL N. W., Chojnice, 19 IX 1947.

108 APB, KPPPRCh, sygn. 2, nlb., Protokół z III Zjazdu Konferencji Powiatowej PPR spisany w dniu 30 III 1947 r. w sali konferencyjnej Hotelu „Urbana” w Chojnicach.

109 APB, KPPPRCh, sygn. 24, nlb., Sprawozdanie z przebiegu zbiórki na wspólny dom zjednoczonej partii robotniczej z pow. chojnickiego, 5 VI 1948.

110 Ibidem.

111 Ibidem, nlb., KP PPR w Chojnicach do II sekretarza KW PPR w Bydgoszczy, Chojnice, $1 \times 1948$.
} 
Centralnego Polskiej Zjednoczonej Partii Robotniczej, który oddano do użytku 1 maja 1952 r. ${ }^{112}$

\section{WNIOSKI}

$\mathrm{W}$ toku prowadzonego badania pozytywnie zweryfikowano przypuszczenia stanowiące hipotezy, że elity polityczne PPR w Chojnicach stanowiły element "narzuconej władzy” w procesie sowietyzacji Polski po 1944 r. Hipotezę pomocniczą stanowiło przypuszczenie, że zjawiska polityczne wynikające z działalności politycznej PPR na ziemi chojnickiej były analogiczne do zjawisk zachodzących w całej Polsce, na szczeblu lokalnym, w wyniku budowania struktur i utożsamiania władzy państwowej z PPR zgodnie z ideologią marksizmu-leninizmu. Ponad to ujawniono, że powiat chojnicki był jednym z najcięższych dla procesów sowietyzacji powiatów w województwie pomorskim, w którym rozwój struktur PPR napotykał wiele barier, od tych natury społecznej po polityczne, wiązane zarówno z żywym zainteresowaniem udziałem $\mathrm{w}$ innych partiach politycznych, takich jak PPS i PSL, jak i działaniami podejmowanymi przez żołnierzy polskiego zbrojnego podziemia niepodległościowego, którzy skutecznie w latach 1945/1946 powstrzymywali PPR przed dynamicznym rozrostem struktur. Ponadto daje się zauważyć periodyzację działań politycznych PPR i życia politycznego na ziemi chojnickiej w latach 1945-1948, która prezentuje się analogicznie do zjawisk ogólnopolskich, czyli do okresu referendum ludowego z czerwca 1946 r., następnie od referendum ludowego do wyborów do Sejmu Ustawodawczego w styczniu 1947 r. i od tych wyborów do zjazdu zjednoczeniowego w grudniu 1948 r., na którym powołano do życia PZPR.

\section{REFERENCES (BIBLIOGRAFIA)}

\section{Archival sources (Źródła archiwalne)}

Archiwum Delegatury Instytutu Pamięci Narodowej w Bydgoszczy:

Wojewódzki Urząd Spraw Wewnętrznych w Bydgoszczy [1945] 1983-1990, Wojewódzki Urząd Bezpieczeństwa Publicznego w Bydgoszczy 1945-1954, sygn. IPN By 049/1.

Archiwum Państwowe w Bydgoszczy:

Komitet Powiatowy Polskiej Partii Robotniczej w Chojnicach, sygn. 1-3, 5, 7, 11, 20, 21, 24.

Powiatowy Komitet Polskiej Partii Socjalistycznej w Chojnicach, sygn. 1.

Starostwo Powiatowe Chojnickie w Chojnicach, sygn. 21.

112 Gmach ten znajduje się przy ul. Nowy Świat 14 w Warszawie, siedzibę miała w nim w latach 1991-2000 Giełda Papierów Wartościowych. 


\section{Studies (Opracowania)}

Baziur G., Armia Czerwona na Pomorzu Gdańskim 1945-1947, Warszawa 2003.

Błażejewski S., Kutta J., Romaniuk M., Bydgoski słownik biograficzny, t. 6, Bydgoszcz 2000.

Buchholc W., Chojnice w latach 1939-1945, Chojnice [b.d.w.].

Chodubski A., Wstęp do badań politologicznych, Gdańsk 2006.

Churska-Wołoszczak K., Referendum ludowe i wybory do Sejmu Ustawodawczego w województwie pomorskim (1946-1947), Bydgoszcz-Gdańsk 2014.

Dembowy B., Romaniuk M., Wstẹp do inwentarza grupy zespołów Komitetów Miejskich i Powiatowych PPR woj. pomorskiego 1945-1948, maszynopis przechowywany w pracowni naukowej Archiwum Państwowego w Bydgoszczy.

Głębowicz B., W Polsce Ludowej, w: Chojnice. Dzieje miasta i powiatu, red. S. Gierszewski, Wrocław-Warszawa-Kraków-Gdańsk 1971.

Golon M., Polityka radzieckich władz wojskowych i policyjnych na Pomorzu Nadwiślańskim w latach 1945-1947, Toruń 2001.

Gontarczyk P., Polska Partia Robotnicza. Droga do władzy (1941-1944), Warszawa 2006.

Kersten K., Narodziny systemu władzy. Polska 1943-1948, Warszawa 1984.

Kozłowski R., Polska Partia Robotnicza w województwie pomorskim 1942-1948, Bydgoszcz 1985.

Kozłowski R., Przyczynek do dziejów ruchu robotniczego w woj. pomorskim w latach 1945-1948, w: 100 lat ruchu robotniczego na Pomorzu, red. M. Wojciechowski, Toruń 1983.

Lorbiecki A., Wałdoch M., Chojnice 1939, Warszawa 2014.

Magier D., Instrukcja organizacyjna Polskiej Partii Robotniczej z 10 września 1944 roku, „Res Historica" 2018, 45

Murawski E., Bój o Pomorze. Ostatnie walki obronne na wschodzie, tłum. G. Bębnik, Oświęcim 2015.

Ostrowski K., W Polsce Ludowej i III Rzeczypospolitej, w: Dzieje Chojnic, red. K. Ostrowski, Chojnice 2010.

Pietrov N., Nowy ład Stalina. Sowietyzacja Europy 1945-1953, Warszawa 2011.

Sowa A.L., Historia polityczna Polski 1944-1991, Kraków 2011.

Sztumski J., Elity ich miejsce i rola w społeczeństwie, Katowice 2007.

Szulczyk K., Polska Partia Robotnicza jako "światła przywódczyni narodu polskiego". Powiat tucholski w rękach komunistów (1945-1948), „Słowo Młodych” 2011-2012, 5, 16-23.

Szumiło M., I sekretarze Komitetów Wojewódzkich PPR (1944-1948) - portret zbiorowy, „Dzieje Najnowsze" 2013, 45, 4.

Trembicka K., Od wroga klasowego do wroga etnicznego - ewolucja komunistycznej myśli politycznej na przykładzie Polskiej Partii Robotniczej i Polskiej Zjednoczonej Partii Robotniczej w latach 1942-1968, „Humanities and Social Sciences” 2015, 20.

Wałdoch M., O chojnickim karnawale "Solidarności”. Kształtowanie się i rola nowego ruchu społecznego w warunkach lokalnych (1980-1981), Chojnice 2015.

Wałdoch M., Obraz podziałów socjopolitycznych wsi chojnickiej w karnawale „Solidarności”, ,Zeszyty Chojnickie" 2015, 31.

Wałdoch M., Polityka faktów dokonanych: Chojnice od 15 lutego do 9 maja 1945 roku we władzy Armii Czerwonej i Polskiej Partii Robotniczej, „Zeszyty Chojnickie” 2016, 32.

Wałdoch M., Sprawa o szpiegostwo Józefa Maculewicza, podkomisarza Straży Celnej w Chojnicach w dokumentach instytucji bezpieczeństwa II RP (1924-1925). Próba rekonstrukcji afery szpiegowskiej, „Studia Gdańskie. Wizje i rzeczywistość” 2014, 11.

Wapiński R., Ruch robotniczy na Pomorzu w latach 1920-1939, w: 100 lat ruchu robotniczego na Pomorzu, red. M. Wojciechowski, Toruń 1983. 
Wapiński R., Życie polityczne Pomorza w latach 1920-1939, Warszawa-Poznań-Toruń 1983. Wrona J., System polityczny w Polsce w latach 1944-1948, „Pamięć i Sprawiedliwość” 2005, 2, 8. Zarycki T., Interdyscyplinarny model stosunków centro-peryferyjnych. Propozycje teoretyczne, „Studia Regionalne i Lokalne” 2007, 1 (27).

\section{Website (Strony internetowe)}

Biblioteka Sejmowa, Baza „Parlamentarzyści polscy”, [hasło:] Jóźwik Józef, https://bs.sejm. gov.pl/F?func=find-b\&request=000002135\&find_code=SYS\&local_base=ARS10 [dostęp: 6 I 2020].

\section{NOTA O AUTORZE}

Marcin Wałdoch - dr nauk społecznych w zakresie nauk o polityce, adiunkt w Katedrze Polityki Bezpieczeństwa na Wydziale Nauk o Polityce i Administracji Uniwersytetu Kazimierza Wielkiego w Bydgoszczy. Zainteresowania badawcze: ruchy społeczne, myśl polityczna, Polonia i Polacy za granica, historia najnowsza, globalizacja, społeczeństwo obywatelskie, migracje, polityka nowozelandzka, samorząd terytorialny i studia lokalne, aspekty polityczne dostępu do informacji publicznej, służby bezpieczeństwa w II RP i PRL. Ważniejsze publikacje: Bliskie antypody: relacje polsko-nowozelandzkie w procesach globalizacji i dywersyfikacji świata (Bydgoszcz 2020); O chojnickim karnawale "Solidarności". Ksztattowanie się i rola nowego ruchu społecznego w warunkach lokalnych (1980-1981) (Chojnice 2015); Chojnicki czerwiec '89. Studium lokalne fali uderzeniowej procesu demokratyzacji (Chojnice 2017); Chojnice 1939 (współ. A. Lorbiecki, Warszawa 2014). 